\title{
Perception Of Female Teachers In Transferring Peace Concepts Among Adult Students
}

\author{
Aziz-Un-Nisa \\ Department of Education \\ University of Karachi \\ Sajida Parveen \\ Department of Teacher Education \\ University of Karachi
}

\begin{abstract}
Peace education attempts to promote awareness of non-violent and positive means of production with conflicts and violent concepts, and to endorse necessary capabilities, knowledge, attitudes and values. This purpose of this empirical study was to examine the Perceptions of Female Teachers in Transferring Peace Concepts among adult Students of public and private schools in Pakistan. However, Mix method, sequential explanatory method was used to attain the objectives of the study. Data of the main study was drawn from students of secondary level of the public and private sector of district Korangi of Karachi, Pakistan. Random sampling technique was employed to select participants of the study. Data was collected equally from both genders. Quantitative data gathered through questionnaire from female teachers and analyzed by using SPSS qualitative data was analyzed with themes. The results of this empirical study revealed that education, schools and teachers are playing influential role in transferring peace concepts and behaviors among adult students it is very vital part of peace building in students and also for their character building. This study concludes that teachers are basic pillar for the building knowledge and behaviors, teachers and educational institution can develop peace concepts and behavior through teaching and developing needs of our violently ill society through mainstreaming peace concepts in education system. Research findings also exposed that Teachers are aware to the meaning and understanding of peace concept to some extent. It was recommended that School atmosphere, teachers, classroom environment, curriculum, activities and concerned school setting should be transformed in such a way to reduce violent actions and conflicted situations in school that will lead to better future citizens.
\end{abstract}

Keywords: Peace Education, Perceptions, Behavior.

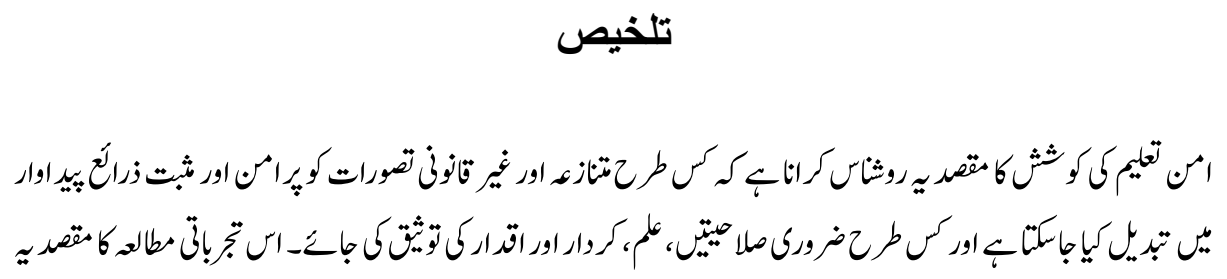




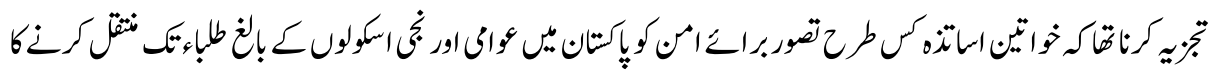

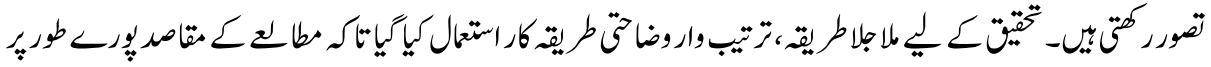

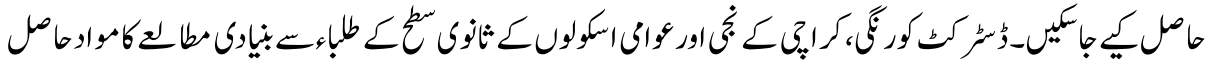

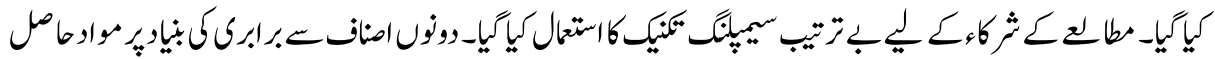

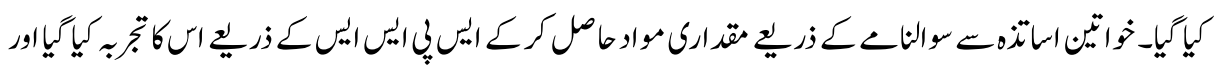

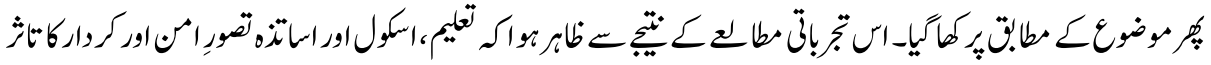

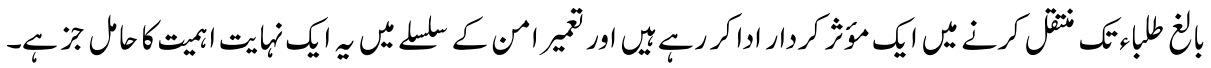

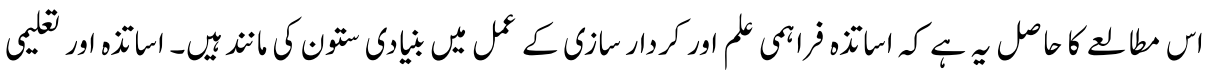

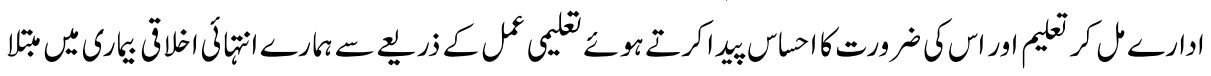

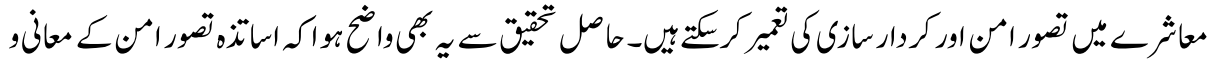

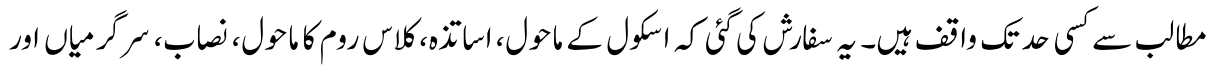

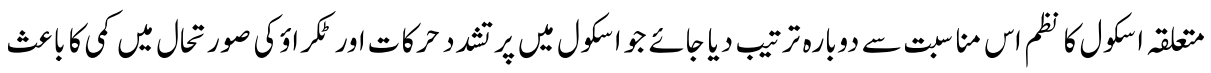

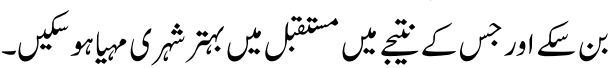

$$
\begin{aligned}
& \text { كليرى الفاظ: يُرامن تعيم، نظريات،رويـ }
\end{aligned}
$$

\section{Introduction}

Peace concepts are based on how to make peace and relates to the learning capacity of human beings. Constructing of universal and sustainable culture of peace, it emphases on obtaining and developing of skills, capabilities, cognition and values. Peace Education incorporates all phases of life and socialization of individuals (Bhatti, 2016; Cohan, 2017). Concept of peace can be imparted through providing awareness for the causes of violence and building abilities and skills to respond positively in conflicted situations (UNESCO, 2005).

Therefore, transferring Peace concept is really based on educational endeavors, either its formal or informal education but it targets that building character, potentials, values and capacities to live with others in concordance, mutual understanding, faith and gracious persistence on conflicts (Omirin \& Funke, 2015). Peace concepts are effectively taught only when embedded within curriculum and classroom practices (Obidike, Bosah \& Olibie, 2015). However, children gain understanding and recognition of social ideals in schools settings (Falade, 2014) and (Luther, 2013) but lack of teacher's positive interactions and adequate school climate has been observed in lessening hostile behaviors and violence from student conduct (Khalid, Yasmeen \& Azeem, 2011). 
Peace education not just depends on producing thoughts and beliefs of society but also can transform the influential form of social perceptions and behavior later on, thinking about educational practices as a power for social revolution from the perspective of basic teaching methods. Gramsci and Foucault developed the deep understanding of education with the relation of power and its influence on knowledge building, who perceived that the way toward developing power and knowledge is not essential for sustaining the existing culture in society but also create and uphold the growing environment for it (Ali, 2013). However, Peace teaching can develop the critical and contemplative thinking in students, required to perceive the truth behind the falsifications produced by the media and influencing sectors of society along with teaching knowledge about violent and nonviolent, conflict and peace, and supportive behavior (Sakade, 2009).

peace education incorporates all the standards, approaches and forms of performance, lifestyles, respect for life, impression of violence, commitment with the code of independence, Integrity, Harmony, patience amongst gatherings and people Hick expounded the purposes of peace education can be gathered into three specifically attainment of skills, understanding about disputes and progression of behaviors. There are various Subjects (Majoni \& Chikasha, 2014) for instances, History, Social Studies, Geography, political and Religious Studies are considered of teaching of peace education. Although students of higher studies also have learned all these in secondary level, so these subjects could empower them in future (Omirin \& Funke, 2015; Luther, 2013).

Eventually, $21^{\text {st }}$ century demands to prepare teachers with knowledge, teaching skills, practices (Lageson, 2017) and personality development (Khan \& Saeed, 2010) with environmental, cultural, biological, ethical, awareness (Mishra, 2011)because teachers can make the decision about teaching practices of peace education methods in schools and academic counselors may guide and supervise programs, teachers frequently planning lessons and suggest students to student advisor and other contributors of peace building. Teachers are essential role models of the reducing violence and promoting productive peace behavior in schools and without teacher's motivation and participation in peace building programs, practices of peace lessons and activities may not be properly conveyed (Redfering, 2014; Dewal, 2012; Evasco, 2015).

However, Pakistan is confronting with the greatest challenge of terrorism and extremism since many years that is subsequently influencing life from various aspects including educational sector. Therefore, the essential for inspecting the active part of institutions in promoting education for peace is the request for every academic professional. Thus, schools give a functioning stage to investigating the circumstances and influential aspect of extremism and attaining a progressive change in the social perceptive and behavior (Bhatti, 2016). But unfortunately, Pakistan's education system still lacking in incorporating the notions of humanity, peace - building and social consciousness of democratic living (Roof, 2015)as well as, public sector demonstrate less appearance in developing peace behavior among students (Bhutto, 2014). 


\section{Problem Statement}

This proposed study intends to examine perceptions of female teachers in transferring peace concepts among adult students. It purposes to investigate the perceptions about role of education in peace building among students of secondary public and private schools of Karachi and determine to point out the differences in perceptions of public and private school female teachers. It also aims to find out the elements of peace education in their related school setting which female teachers usually experience during conveying peace concept among adult students.

However, the rationale of this topic is that peace education is essential need to aware the society regarding peace education and handles all the bad situations intellectually related to human social life. Education develops all the hidden skills and talents of individual that is why education is best option for developing peace behavior through peace education among students. Peace education emphasizes to create co-operation and harmony through developing specific skills and attitudes by dealing social conflicts and develop understanding respect and tolerance towards opponents.

Therefore, teachers can perform a vital role to aware about peace and its elements for adopting such great abilities as a coping skill through teaching and transferring peace conceptions and behavior. Although, Students need to clear their concepts regarding peace in order to develop their overall personality and character building. The problem of research is generally related to the overall productivity, performance and academic achievement of a student.

\section{Research Questions}

1. What is the perception of female teachers on the role of peace education in peace building at secondary level?

2. Is there any significant difference in the perception of female teachers of private and public schools on the impact of peace education among adult students?

3. What is the understanding of female teachers about peace concepts to find out the peace elements in their present school settings?

\section{Objectives of the Study}

1. To examine the perception of female teachers on the role of peace education in peace building at secondary level.

2. To inspect whether there is difference in the perception of female teachers of private and public schools on the impact of peace education among adult students. 
3. To explore understanding of female teachers about peace concepts in order to find out the peace elements of in their present school settings.

\section{Significance of the Study}

However, the study may reveal contributions of female teachers in transferring peace concepts among adult students. Teachers are often privileged for the responsible and monitorial role that can edify the society regarding social distinction, inequality, social control and violence. Whereas, it is need to bring changes into schools by empowering pupils and teachers through learning and practicing peace education. Academic aspects of this study can also inaugurating practical outline for peace education and can lead to the development. This study could significantly play supportive role for teachers, administrators of schools, parents and society in the practices of peace education.

Moreover, it involves nonstop practical proficiency and guidance of teachers about adoption of the program peace education that may help to achieve targets of schools. Teachers are directly and government, institutions, educational authorities, NGOs indirectly accountable for the practices of the peace education in schools settings.

\section{Hypothesis}

H1: Female teachers perceive that peace education influence in peace building at secondary level.

$\mathrm{H} 2$ : There is significantly difference between in the perception of female teachers of private and public schools on the impact of peace education among adult students.

H3: Female teachers can positively understand peace concepts and peace elements in their present school settings.

\section{Literature Review}

Falade, (2014) stated that Freud indicated, humanoid are innate the nature that features all performances of violence and ruin. The violent behavior of a person can be released by unfortunate actions such as: abusive behavior with others, battling or damages things. Adults quickly adopt violent behavior by observations (Salomon \& Cairns, 2011). They pick up all violent and destructive actions through observation from other people of society as (Pró-Paz, 2005) stated that in the point of view of social psychologists aggressive and violent behavior cannot be adopted by birth or gene but it is built by social interaction from society.

It is perceived those adults who saw or nurtured under war they have high warring inclinations than adults who nurtured without facing war conditions. Teachers, guardians, 
and caretakers are responsible to make a culture of peace by living in sociability with each other to ensure as role models. Thus, it's essential that Kids should be taught peace concepts, social justice, human rights, values and norms and other elements of peace related living style. Peace can be perceived not just as the absence of violence, conflict and war but as a positively existence including prosperity, social equity, uniformity, social justice, human rights and basic necessities of all (Obidike, Bosah \& Olibie, 2015).

Omirin \& Funke, (2015) indicated that according to "Encyclopedia of 2015" peace education is a way of getting information, awareness and fundamental values likewise, developing talents, learning abilities and building up the personalities, abilities and conducts to live with coherence along with all the creations of this universe.

Furthermore, he explained that The United Nations (2009) exposed the concept of peace education. It can be demonstrated in terms of schooling and co-curricular activities that:

$>$ It plays a role as unit of peace, where learners are protected from violent and conflict type behavior.

$>$ It advocates children's fundamental rights which was drown in convention on the right of child (CRC);

$>$ Build up stimulating environment to shape peaceful behavior for all learners.

$>$ Exhibit the standards of uniformity for executive strategies and applications.

$>$ Aware about the peace building in terms of existence in society, incorporating methods for managing conflict that are compelling, peaceful, and established in the native culture.

$>$ Grip the clashes in regard that rights and respect.

$>$ Incorporate the curriculum with all the essential awareness of peace, human rights, social justice and global barriers.

$>$ Offer a platform for indisputable dialogue on peace and social judges;

$>$ empower children to implement peace in school setting and in society extensively;

$>$ create the open doors for constant reproduction and expert advancement of all instructor related to issues of peace, justice and rights;

While, Ian Harris John Synott proposed that peace education is teaching experiences which draw from society as wish for peace, Non-violent substitutes for coping conflict and Expertise for deep inquiry of operational activities that deliver and legitimize unfairness and imbalance (Omirin \& Funke, 2015).

However, Education is an essential instrument for perfection of humanity and the destruction of neediness (National Education Policy, 2017). It is the way by which other future followers can build up the qualities, information and aptitudes for their own wellbeing and security and for future political, financial, cultural and social innovation. 
This is the biggest motivation behind why the MDGs put such a great amount of highlighting on accomplishing wide spread, free and mandatory education by the program Education for All (EFA). As far as connections between education and process of peace education, education generally plays a conventional role. Peace education supposed to include tutoring kids and youth with educational programs related to peace for their selfimprovement, diverse groups and conflict managing approaches (Smith, 2011). According to "Peace Education Framework for Teacher Education, (2005)"Peace education is allinclusive because it grips all aspects of child development with the background of conventional human values. It depends on a rationality that shows affection, sympathy, trust, decency, unity and love for family and all living creation of this planet.

Furthermore, the essential notion is implanted in the above explanations that peace education is an educative measure to protect youngsters from violent behavior of society. It intends overall improvement of the adults and attempts to teach higher human and social values to the learners. Generally, peace education builds essential behavioral skills and peaceful living for peace building from which the beneficial need of entire humankind).

Sri-Amnuay, Aree (2011) clarified the addition of the peace researches in the last of $20^{\text {th }}$ century requested that it has a very mutual connection with peace related activities, peace research, and peace education by educators and campaigners to caution individuals about harm of violence. Teachers supposed to train students by peace activities that how to cope with conflicts in different environmental setting. Thus numerous other intellectuals and scholars portrayed different definitions, goals, elements and teaching methods of peace education.

Peace education has broad and narrow perspective and values, morals, attitudes, aptitudes and abilities are as under of its objectives. Scenarios of Implementation of peace education is different while, occurring in areas of conflicts often concentrate of decreasing violence and give it other related place. Though, the research is favorable that it is absolutely not convincing with regards to the arrangements of components for its effectiveness. These projects rely upon school staff to stay operational and durable (Redfering, 2014).

Sakade, (2009) argued that peace education can be viewed as a conceivable method for changing present prevailing violent culture inn to peace culture by bringing up students peaceful states of mind and behavior and alter their perceptions as well as he revealed that peace education can transform their concepts and behaviors. Peace education generally endorses healthy thoughts, awareness of respect and tolerance towards conflicts and violence at an aggregate level by concentrating on inhibition of conflicts, impartiality and lives together real opponents. The other hand, peace education generally in 
established societies highlights co-activity and sociability by creating individual's aptitude in managing clashes and interactive conflicts.

Smith, (2011) stated that the hypothetical writing on peace building shows an essential discrepancy between two types of peace "negative peace" as known the termination of violence, the other type is "positive peace" as operational change that report social prejudice which is actual reason of violence. Peace education means "not to hurt" and add peace building with the help of post-conflict change. Most of the peace education programs are not prearranged from a peace building point of view. Continue peace building programs are essential. Peace building programs needs attention and progressive schedule to transformation of peace building as well as education needs to connect with the United Nations peace building design.

Omirin \& Funke, (2015) prescribed urging the understudies to love the world and realize peaceful future; and encourage them for adopting caring behavior. Teachers have chances on daily bases to polish student's capacities to convey the concepts of respect to each other, cope to conflicts and implement services of social accountability which will transmit into adulthood, incorporation of peace making abilities in the educational programs is imperative as figuring out how to read and compose. Thus for building a culture abiding it is essential to teach peace concepts to adults and teachers can do this by managing a peaceful classroom environment and educating pupils' conflict resolution and social account ability for themselves, the other people of world and the curriculum must be incorporated with the concepts of peace (Jäger, 2011). Actually, social environment and curriculum can be formed by empower youngsters need to learn (Hamman, 2017; Bartlett, 2009) constructive ideas about how individuals can live with harmonization. There are four steps are suggested that how to resolve conflicts, as mentioned in the table below

\begin{tabular}{|l|l|}
\hline \multicolumn{1}{|c|}{ Step } & \multicolumn{1}{c|}{ Action } \\
\hline Speak about the problem & Permit to speak to define. \\
\hline Precisely explain & Precisely explain students points of views \\
\hline $\begin{array}{l}\text { What is the solution in } \\
\text { your perspective? }\end{array}$ & $\begin{array}{l}\text { Take all possible solutions from all aspects, teacher can say } \\
\text { 'maybe there is another way of solution,' but do not force } \\
\text { them for anyone to choose. }\end{array}$ \\
\hline $\begin{array}{l}\text { Support the student to } \\
\text { choose solution }\end{array}$ & $\begin{array}{l}\text { Do not give any hint of what you think they should do. It is } \\
\text { their decision. }\end{array}$ \\
\hline
\end{tabular}

All the four stages ought to be clarified so that all the queries could be removed. In very short duration youngsters could learn to use these strategies unconventionally (Obidike, Bosah \& olibie, 2015).

While, there are some Issues and challenges related to teachers as a component of postconflict peace building incorporate the difficulties of restoring teaching capability as well 
as some are concerned with vacancies, teaching trainings, promotion of qualifications, increasing wages, and. terms and states of work related plans and policies. Teachers are suggested to be a part of post-conflict peace building program in order to establishment of trained teachers due to make them aware about their worth and strategies for the dialogue on questionable issues (Smith, 2011).

However, schooling is always assessed as reasonable department for the production social differentiation, discrepancy, violence and social conflicts. These qualities of schooling are seen as challenges for peace building; the idea of peace education can be conflicted in many ways. Though, teachers have to bring changes into schools by engaging students and educators through teaching and practicing (Gopang, 2016) and (Sakade, 2009).

The School is occupied with co-curriculum activities for guardians and with the existence widely in society. Peace education programs incorporating of social coordination influence positively on participants behavior towards peacefulness. The outcome empowers endeavors for peace education in tragedies and conflict situations. Peace education is not alone or permanent approach to resolve conflicts peacefully but it can help for resolution the problems (Lenhart, 2014).

Hence, to achieve successful consequences related to peace building, the teaching and learning of peace process must be the type that enables students to show the inborn peace values and aptitudes amongst themselves. The successful and effective peace building activities develops and support the environment to make a situation strong of selfsupporting, long-lasting peace, opponents collaboration, keep safe from resuming conflicted situations, incorporate common society; make the rules for law system, and address basic operational and societal barriers and challenges (Falade, 2014).

\section{Methodology}

According to the objectives, sequential explanatory mix- method was used for this research study. The explanatory design starts with guidelines the gathering (Hesse-Biber, 2010) data and inquiry of quantitative data in the first phase (Creswell, 2008). Construction of the explanatory results, the researcher has to conduct qualitative data in the second phase for generalizing the quantitative findings. After that, the researcher interprets how the quantitative results construct on the qualitatlive results. Quantitative strategy of the study is survey research (Creswell, 2014; Howitt\& Cramer, 2010). Surveys research a research method comprising the use of questionnaires and statistical methods (Cohen, 2007) to collect data about people and their thoughts and behaviors while, Phenomenological study is selected to perceive the phenomenon from teacher's perceptions qualitatively (Given, 2008). 


\section{Conceptual model}

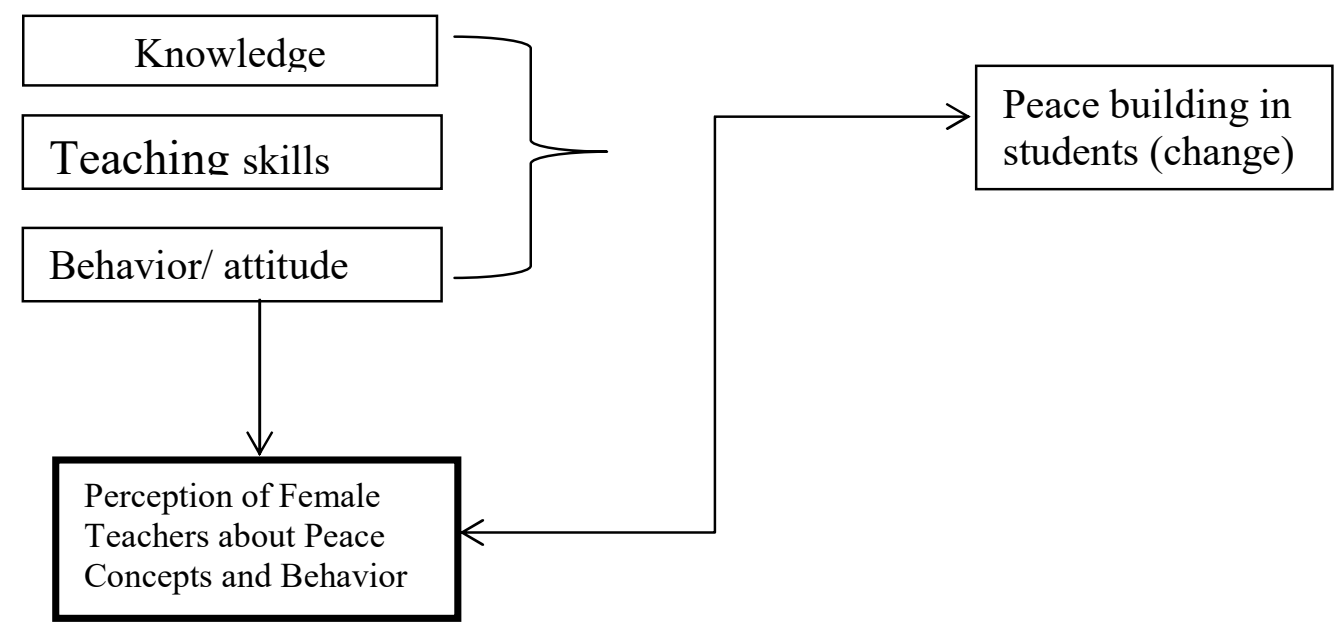

*The conceptual model is developed by researcher

\section{Data Collection}

The data for the study is gathered through questionnaires and interviews. The focus was on collecting information through reliable resources. It is one kind of research through which data can be collected by filling out questionnaires. To gain comprehensive understanding of the phenomenon the quantitative data were gathered through survey. The interviews were informally taken with their written feedback in order to analyze for categorizing key themes to present qualitative findings.

\section{Population and Sampling}

Sample of the study were adopted randomly; 5 public and 5 private schools were selected from Korangi district of Karachi. Sample of the study were adopted randomly from the population. Questionnaires were filled out by 100 female teachers of public and private secondary schools, for examine their conceptual understanding and behavior related to peace education. However, 10 female teachers and 10 students from public and private schools were purposely interviewed.

\section{Research instruments}

However, the research tools were adapted from two sources by (Omirin \& Funke, 2015; McGhee, Lowell \& Lemire, 2007) and developed according to the context by the researcher. A survey questionnaire was consist of 30 items on five point Likert scale from $1=$ strongly agree, $2=$ agree, $3=$ to some extent, 4=disagree, 5=strongly disagree. It 
comprised of 10 items for measuring teacher's knowledge (TK) regarding peace concepts, 09 items for measuring teacher's skills (TS), 11 items for measuring teacher's attitude (TA) in promoting peace conceptions among students of public private schools of district Korangi of Karachi. SPSS were used for the analyzing quantitative part of the study in order to understand conceptions of female teachers and also the data material were analyzed with the results and then interpretations were obtained in the form of tabulation.

While, the qualitative data were presented by thematic analysis related to perceptions of female teachers. A semi structured Interview with 10 items were prepared for female teachers and students of public private schools of district Korangi of Karachi.

\section{Reliability of Instrument}

Internal consistency of each variable has done for checking the reliability analysis. Moreover, the Cronbach's alpha value of this study is 0.82 which means $82 \%$ and shows that the reliability of the data is acceptable.

\section{Data Analysis}

The proposed research is designed to investigate the perceptions of female teachers in transferring peace concepts among adult students in terms of their knowledge, attitudes, and skills. The results show the analysis of demographical variable as presented in terms of teaching experience, Educational Qualification of teachers.

\section{Ethical consideration}

There is some consideration which must be considered as names of respondents ought to be enclosed to other individuals. In such case, a strict code of ethics that transcript material is fundamental to secure all gatherings and the trustworthiness of the research process.

Therefore, these moral considerations are essential for this research is concerned that trust and morality are assured at the primary spot so as to get answers from the questionnaire. The members were taken in strict confidence and were not enforced by the researcher or institution. It was obviously showed that the information they gave must be confidential and name and schools name won't be specified without approval. It frames a sound evidence of successful correspondence from both respondents and researcher. In order to exclude possible contradictions and uncertainties, a copy of the consent form which is attached to the questionnaire was provided upon request place by the researcher. 


\section{Results and Discussion}

Quantitative Findings: Demographics Analysis

Table: 1

Teaching experience

\begin{tabular}{|l|c|c|c|}
\hline & Frequency & Percent & Valid Percent \\
\hline 1-10 years & 20 & 20.0 & 20.0 \\
\hline 10-20 years & 49 & 49.0 & 49.0 \\
\hline 20-30 years & 24 & 24.0 & 24.0 \\
\hline 30-40 years & 7 & 7.0 & 7.0 \\
\hline Total & $\mathbf{1 0 0}$ & $\mathbf{1 0 0 . 0}$ & $\mathbf{1 0 0 . 0}$ \\
\hline
\end{tabular}

Table: 2

Academic qualification

\begin{tabular}{|l|c|c|c|}
\hline & Frequency & Percent & Valid Percent \\
\hline Bachelor & 60 & 60.0 & 60.0 \\
\hline Masters & 20 & 20.0 & 20.0 \\
\hline M.Phil & 20 & 20.0 & 20.0 \\
\hline Total & $\mathbf{1 0 0}$ & $\mathbf{1 0 0 . 0}$ & $\mathbf{1 0 0 . 0}$ \\
\hline
\end{tabular}

Table: 3

Professional qualification

\begin{tabular}{|l|c|c|c|}
\hline & Frequency & Percent & Valid Percent \\
\hline B.Ed & 54 & 54.0 & 54.0 \\
\hline M.Ed & 46 & 46.0 & 46.0 \\
\hline Total & $\mathbf{1 0 0}$ & $\mathbf{1 0 0 . 0}$ & $\mathbf{1 0 0 . 0}$ \\
\hline
\end{tabular}

Table: 4

Teachers by sector

\begin{tabular}{|l|c|c|c|}
\hline & Frequency & Percent & Valid Percent \\
\hline Public Teachers & 57 & 57.0 & 57.0 \\
\hline Private Teachers & 43 & 43.0 & 43.0 \\
\hline Total & $\mathbf{1 0 0}$ & $\mathbf{1 0 0 . 0}$ & $\mathbf{1 0 0 . 0}$ \\
\hline
\end{tabular}

By the demographic results following conclusions are drawn:

- Table No. 1 shows the results about "Teaching experiences" that majority of the respondents have 10-20 years of experience, with the frequency of 49 and percentage of $49 \%$.

- Table No. 2 shows that majority of the respondents have bachelor Degree with the frequency of 60 and percentage of $60 \%$ by Academic Qualification.

- Table No. 3 shows the results about "professional qualification" that most of the respondents have B.Ed. degree with the frequency of 54 and percentage of $54 \%$. 
- Table No. 4 indicates that majority of the respondents are public schools female teachers with the frequency of 57 and percentage of $57 \%$ while $43 \%$ of respondents are public schools female teachers with the frequency of 43.

\section{Item Analysis}

Mean rating \& standard deviation on the extent to which female teachers possess knowledge (TK), skills (TS), Attitude (TA) regarding peace education at secondary level.

Table: 5

\begin{tabular}{|l|c|c|}
\hline \multicolumn{1}{|c|}{ Item statement for teachers knowledge (TK) } & Mean & SD \\
\hline Peace is a practice of discouraging war and violence. & 3.050 & 1.402 \\
\hline Peace is to understand feelings of others. & 2.900 & 1.314 \\
\hline Peace is meant to promote a culture of tolerance. & 2.950 & 1.282 \\
\hline Peace must be built on a local level in our society. & 2.970 & 1.258 \\
\hline $\begin{array}{l}\text { Peace is considered in absence of violence and it is respect and } \\
\text { acceptance for others. }\end{array}$ & 4.0300 & 1.381 \\
\hline Peace education is a proper way to develop living in Pakistani society. & 4.0400 & 1.154 \\
\hline Peace is meant to maintain mental, verbal and physical absence of violence. & 3.1500 & 1.513 \\
\hline Students need peace knowledge and skills in our society & 3.1600 & 1.851 \\
\hline Peace Education could be taught through games, songs and plays. & 3.1600 & 1.851 \\
\hline Peace education is important to reduce crime. & 3.1600 & 1.405 \\
\hline
\end{tabular}

The mean values of items of (Table 5) shows that female teachers of secondary schools possess knowledge to some extant regarding the conception of peace education.

Table: 6

\begin{tabular}{|l|c|c|}
\hline \multicolumn{1}{|c|}{ Item statement for teachers skills (TS) } & Mean & SD \\
\hline Our curriculum provide a good sense of citizenship among students & 3.1800 & 1.559 \\
\hline $\begin{array}{l}\text { Inculcating peace skills among students required additional training for } \\
\text { female teachers }\end{array}$ & 3.1800 & 1.559 \\
\hline Teachers guide in promoting the sense of cooperation among students & 3.2200 & 1.521 \\
\hline You taught students to display openness towards other cultures. & 2.910 & 1.349 \\
\hline You taught students to show tolerance in the classrooms fights & 2.960 & 1.332 \\
\hline Peace and harmony are significant parts of your lessons taught in class & 2.900 & 1.314 \\
\hline $\begin{array}{l}\text { You encourage the sense to appreciate different cultures and languages } \\
\text { among students }\end{array}$ & 2.880 & 1.387 \\
\hline Students are taught to work in co-operation with others & 2.810 & 1.383 \\
\hline Classroom activities provide the sense of efficiently using the resources & 2.960 & 1.332 \\
\hline
\end{tabular}

The mean values of items of (Table 6) shows that female teachers of secondary schools have skills in transferring peace concepts among adult students. 
Table: 7

\begin{tabular}{|l|c|c|}
\hline \multicolumn{1}{|c|}{ Item statement for teachers attitude (TA) } & Mean & SD \\
\hline You try to be fair with every student & 2.900 & 1.314 \\
\hline I always behave sensibly to people & 2.910 & 1.303 \\
\hline You approach students with tolerance & 2.9200 & 1.098 \\
\hline You are against every kind of verbal and physical punishment & 3.1500 & 1.513 \\
\hline You try to promote sense of cooperation among students & 3.1600 & 1.851 \\
\hline You try to respect the rights and freedom of others & 4.0300 & 1.381 \\
\hline You appreciate to promote respect for different cultural groups & 4.0400 & 1.154 \\
\hline I try to promote sense of cooperation among students & 4.0600 & 1.032 \\
\hline I value the cultural diversity. & 4.1200 & 1.997 \\
\hline You are against every kind of verbal and physical punishment & 3.2200 & 1.521 \\
\hline You provide chances to promote team-building spirit among students & 3.2200 & 1.521 \\
\hline
\end{tabular}

The mean result of items of (Table 7) indicates that female teacher's attitude is not in satisfactory mode in present situation.

\section{Hypothesis Analysis}

\section{H1: Female teachers perceive that peace education influence in peace building at secondary level}

Item analysis indicates the result beside $\mathrm{H} 1$ that most of the respondents view that providence of peace concepts through peace education as the most important way to inculcate peace living nature among the members of Pakistani. While, female teachers suggest that curriculum can help in promoting the sense of co-operation, sense of citizenship. Though, in regards to teacher's opinion the present text books don't probe the demanding needs of society and current societal conditions. Hence, female teachers argued that in addition to inaccessibility of peace notions in curriculum, also to some extent teacher's training is needed for the infusing peace elements through subject perspective and teaching role.

\section{H2: There is significant difference between in the perception of female teachers of private and public schools on the impact of peace education among adult students}

Item analysis revealed the result beside $\mathrm{H} 2$ that Female teachers at public and private schools of secondary level possess the average knowledge regarding the conception of peace in context to the society and school setting when they are familiarizes to some extent regarding the meaning of peace in terms of promoting the culture of tolerance with respect and acceptance for others in society. The result shows average condition in pursuing peace relevant skills among teachers at public school level. 
The results indicate that attitude of female teachers at public and private schools of secondary level towards student in terms of symbolizing peace is acceptable to some extant of average level of response at the present situation in public schools. As the results highlight that in average private school female teachers show positive responses regarding the fact they implicit fair and unprejudiced behaviors towards students. Further, promoting and appreciating the sense for respecting different languages and cultures score is an average level among all the means shown in the above table. For the analyzing, regarding different perceptions of private and public teachers the researcher used independent t-test in order to authentication of the result.

Table: 8

Independent sample t-test

\begin{tabular}{|c|c|c|c|c|c|}
\hline \multicolumn{9}{|c|}{ Group Statistics } \\
\hline & Teachers & $\mathrm{N}$ & Mean & Std. Deviation & Std. Error Mean \\
\hline \multirow{2}{*}{ TK } & public & 57 & 38.6842 & 4.67958 & .61983 \\
\cline { 2 - 6 } & private & 43 & 37.6279 & 4.57229 & .69727 \\
\hline \multirow{2}{*}{ TA } & public & 57 & 41.4211 & 4.90607 & .64983 \\
\cline { 2 - 6 } & private & 43 & 40.9302 & 5.27074 & .80378 \\
\hline \multirow{2}{*}{ TS } & public & 57 & 34.3333 & 3.60720 & .47779 \\
\cline { 2 - 6 } & private & 43 & 34.2791 & 4.00788 & .61120 \\
\hline
\end{tabular}

Table 7 revealed that there is no difference exists between the means of perceptions of private female teachers and public female teachers related to teacher's knowledge, teacher's skills and teacher's attitude regarding peace concepts.

Table: 9

Independent samples test

\begin{tabular}{|c|c|c|c|c|c|c|c|c|}
\hline Groups & Teachers & $\mathbf{N}$ & Mean & SD & F & df & Sig. & t \\
\hline \multirow{2}{*}{ TK } & Private & 43 & 1.05630 & .93600 & .061 & 98 & .262 & 1.129 \\
\cline { 2 - 9 } & Public & 57 & 1.05630 & .93293 & & 91.672 & .260 & 1.132 \\
\hline \multirow{2}{*}{ TA } & Private & 43 & .49082 & 1.02319 & .369 & 98 & .633 & .480 \\
\cline { 2 - 9 } & Public & 57 & .49082 & 1.03360 & & 86.978 & .636 & .475 \\
\hline \multirow{2}{*}{ TS } & Private & 43 & .05426 & .76435 & .093 & 98 & .944 & .071 \\
\cline { 2 - 9 } & Public & 57 & .05426 & .77578 & .061 & 85.164 & .944 & .070 \\
\hline
\end{tabular}

Table 8 An independent sample t-test was employed the table shows that there was no significant difference in perceptions of private and public female teachers regarding transferring peace concepts among adult students related to teacher's knowledge (TK) $t$ $(91.672)=1.132$ where $p=.260$ which is $>0.05$, teacher's attitude (TA), t $(86.978)=$ .475 where $\mathrm{p}=.636$ which is $>0.05$, teacher's skills $(\mathrm{TS}), \mathrm{t}(85.164)=.070$ where $\mathrm{p}=$ .944 which is $>0.05$. Thus, it may be concluded that research's hypothesis $(\mathrm{H} 2)$ is rejected and null (Ho) hypothesis is accepted. 


\section{H3: Female teachers can positively understand peace concepts and peace elements in their present school settings}

Table No 5 revealed the result beside $\mathrm{H} 3$ that female teachers try to promote the elements and essences of peace in sense of lesson explanation and classroom management style. Though, results of the study indicate that students are being taught about showing tolerance in class conflicts. Furthermore, conventional efforts in instructing the ideals of environmental care, sense of co-operation, teamwork, acceptance for other cultures and using resources in efficient manner were noted by means of teaching.

\section{Qualitative Findings: Thematic Analysis}

Six major themes were derived from 20 interviewees. In addition, the proposed research also highlights female teacher's perceptions regarding peace related issues or topics that should be considered in present educational settings according to their opinion. There are three research questions which are investigated and qualitative results proposed the answers of these questions.

\section{R.1: What is the perception of female teachers on the role of peace education in peace building at secondary level?}

$>$ Theme 1: Educating Peace for Living Together

$>$ Most of the Female teachers and students define that "Peace build good relation in all of us and our religion" also say "peace should built for all people of the world". Some students responded that, peace mean is to live with family, teacher, neighbor and all persons cooperatively.

Theme 2: Thinking \& Acting Positively

$>$ All respondents answered the concept of peace to be built by holding positive activities that favor mutual living and sound peace in life of self and others as explained "peace is like unity with other. do kind thing with people friend and parents and "Good person do good things". Also answered "Peace mean loves, humanity, helping people, speaking truth, obey elders and live with each other in happiness".

$>$ Theme 3: Respect for Human Dignity

> Many of the female teachers and some students responded that "Peace in real life is to live for humanity and with each other to live with humanity and take care for others human respect". "Peace is a word which aware all people to love each other not hating" and stated that Peace tells us to respect poor, rich, multi-cultural and divers people of the world" and also replied "peace is to live with honesty and be responsible citizen in country". 


\section{R.2: Is there any significant difference in the perception of female teachers of private and public schools on the impact of peace education among adult students?}

\section{$>$ Theme 4: Peace killing Disputes}

However, during the collaboration phase majority of the students were probed to share their some negative experiences in present school setting in relevancy to practices related to peace which is considered as peace killing disputes as negative theme of this proposed study.
- Bullying
- Teacher's angry mood
- Mistreatment with students
- Politicize behavior of teachers
- Favoritism
- Teacher's rudeness
- Teacher's negligence in meeting parents
- Use of harsh wordings with students
- Non-cooperative attitude of teachers

Most of the participants responded that, "the present learning material at public school level is inadequate with the factual need and less presents the topics in relevancy to peace concepts". Though, some responded "the present public school setting female teachers denote unsatisfactory attitude with students during teaching". Some teachers said "public school teachers possess deficient level of skills regarding peace infusion among students".

\section{R.3: What is the understanding of female teachers about peace concepts to find out the peace elements in their present school settings?}

Theme 5: Care \& Concern to the Earth

Most of the participants explained their opinion that "peace can be made as the Way of living happily with all human and look after animals, plants, our homes and life need".

Moreover, they also viewed that "acting positively and regarding respect for humanity, peaceful living also demands human concerns for the other perceptible creations of planets like plants, animals, climatic atmosphere and others".

$>$ Theme 6: Be Kind \& Resolve Conflicts

Most of the respondents appreciated and defined the elements of peace as "love, care, kindness, generosity, help, trust, sharing, and tolerance as key subject in promoting peace among students and other people". Some of the students probe the importance of "live with cooperation and not fight with others". Another student shared the opinion as regarding peace "to live in brotherhood and positing sense of caring for others". 


\section{Discussion}

Afterwards, by merging both the quantitative analysis phase and qualitative analysis phase, this piece of research inferred some noticeable key assumptions as issues in concern to the promotion of peace concepts and behavior and implying peace practices within the school premises and among student's physical, social and emotional level of improvement.

Key issues related to peace education

- Teacher's rudeness

- Personal antagonism

- Student labeling

- Out dated curriculum

- Lack of positive attitude

- Exclusive behavior

- Lack of humanism

- Lack of teacher's training

- Lack of interest in promoting betterment

- Lack of respectable and honorable place for teachers

During the research study it is observed that teachers and students perceive importance of peace education they want change in educational, social system of Pakistan. They aware related to insufficiency majority of teacher's conduct in transferring peace concepts and behaviors among students in schools and lack of research studies on awareness for peace education at national and local level in the context of Pakistan. Further, inconsiderable weight age has been given for including peace relevant material curriculum.

\section{Conclusions}

This proposed study aims to explore the perceptions of female teachers in transferring peace concepts and behavior among adult students which is most strong part of peace building in students and also for their character building. This study intended to probe the unobserved attention towards the pre- requisite culture of peace and developing needs of our violently ill society through main streaming peace ideals in education system. Conclusions from the analysis of both QUAL \& QUAN phases of research study are enlisted as:

- Concepts of civic education, citizenship, democratic living and individual development were lacking properly in curriculum.

- Research findings also revealed that students are lacking in overcoming their individual issues and societal conflict.

- Teachers are aware to the meaning and understanding of peace concept to some extent. 
- Presenting appropriate skills that enable peace among learners was not of main concern for the public school teachers.

- Students also demonstrate the inadequate school setting and disappointing behavior of teachers towards students as the major hurdle in maintaining peace and harmony among student.

- Fewer amounts of teachers posit practices of peaceful attitudes towards students during school setting.

- Teachers pointed that the curriculum is not in appropriateness to the needs and conditions of our living society and should be reformed.

\section{Recommendations}

Following research recommendations were drawn after the in-depth examination of the present research study,

- School atmosphere, teachers, classroom environment, curriculum, activities and concerned school setting should be transformed in such a way to reduce violent actions and conflicted situations in school that will lead to better future citizens.

- Re-structuring the existing curriculum on the basis of present-day societal needs and in accordance with the mental demands of students will aid in bringing better learners.

- Curriculum should be upgraded to provide the developing sense of good citizenship, sense of responsibility and moral sense among its learners.

- Practical approach for promoting culture of peace and its instilling in curriculum required qualified and trained teachers for teaching theoretical content and fostering peaceable thinking and attitudes among learners.

- It is recommended by the researcher that further studies could be conducted with other variables of teaching methods, co-curricular activities, classroom management style, school administration, teacher's training and development within the education system.

- Moreover, another recommendation for the research requires the comparative analysis of present school teachers with untrained and accessible knowledge with the professionally trained teachers who are being qualified and skilled related to peace education, conflict resolution, human rights education and democratic education perspectives.

\section{References}

Alan Smith, E. M. (2011). The Role of Education in Peace Building Literature Review.United Nations Children's Fund (UNICEF). New York. 
Bartlett, T. A. (2009). Teaching Teachers to Teach Peace:A Reflective Pre-Service Case Study. Toronto: Teaching and Learning Ontario Institute for Studies in Education University of Toronto.

Bhatti, R. (2016). Libraries and Education for Peace in Pakistan. National Conference Organized by Pakistan Library Association. Bhawalpur.

Cohan, C. F. (2017). John Dewey and the Significance of Peace Education in American Democracy. The Journal of the Gilded Age and Progressive Era, vol.16:4, pp.456-47.

Creswell, J.W. (2008). Educational Research: Planning, Conducting and Evaluating Quantitative and Qualitative Research (3rd Ed.). Upper Saddle River, New Jerrsy: Pearson Education. Inc.

Creswell, J.W. (2014). Research Design: Qualitative, Quantitative and Mixed Methods Approach ( $4^{\text {th }}$ Ed.). Thousand Oaks, California: SAGE Publications, Inc.

Dewal, O. S. (2012). Peace-Oriented Teacher Education Curriculum. Gandhi Vidhya Mandir, "International Seminar on Gandhi Vidhya Mandir, "International Seminar on . Dehli.

Evasco, K. E. ( 2015). The Integration of Values in the Teaching of Social Sciences. International Journal of Education and Social Science, 2(6).

Falade, D.A. (2014). Proposal for the Inclusion of Peace Education in the Universal Basic Education Program in Nigeria. American International Journal of Research in Humanities, Arts and Social Sciences, vol.7:1, pp.06-10.

Gopang, Illahi. (2016). Teacher Education and Professional Development Programs in Pakistan. International Journal of Research in Teacher Education, vol.7, pp.1-14.

Hamman, A. A. (2017). Inclusion of Peace Education in Teacher Education Programme Curriculum: Tool for Promoting Peace and Unity in Nigeria. Interdisciplinary Journal of African \& Asian Studies, vol.1:3.

Hesse-Biber, S. N. (2010). Mixed Methods Research: Merging Theory with Practice. New York, London: Guilford Publications, Inc.

Howitt, D. \& Cramer, D. (2010). Introduction to Research Methods in Psychology (3rd ed.). Harlow, England: Prentice Hall. 
Jäger, U. (2011). Peace Education in the $21^{\text {st }}$ Century. Peter Becker Award for Peace and Conflict Studies, Institute for Peace Education Tuebingen, Peace and Conflict Studies, Marburg.

Khalid, A.,Yasmin, S. \& Azeem, M. (2011). Impact of Teacher's Background and Behavior on Students Learnin. International Journal of Human Resource Studies, vol.1:2, pp.2162-3058.

Lageson, T. M. (2017). A Qualitative Case Study of Teachers' Perceptions and Practices in Social Justice Education and the Perceived Implications for K-2nd Grade Children . Ed.D. Dissertations Graduate Theses \& Dissertations. Portland: Concordia University.

Lenhart, V. (2014). Peace Education in Conflict Areas- the Role of Philanthropic Institutions. Germany Paper Presented at the International Conference on Philanthropy and Peace Building Istanbul. Istanbul.

Luther, V. (2013). Importance, Indifference or Intolerance: A Study of Pre-Service Educators' Perceptions and Attitudes toward Teaching Social Studies in the Elementary Grades. The Georgia Social Studies Journal, vol.3:3, pp.138-148.

M.Given, L. (2008). The SAGE Encyclopedia of Qualitative Research Methods. 1072. Swinburne, Australia: SAGE.

Majoni Cuthbert \& Chikasha Jennifer. (2014). Factors Affecting Teaching Practice Assessment in Teachers' Colleges in Zimbabwe and their Implications on Professional Development of Student Teachers. Greener Journal of Education and Training Studies,vol.2. 012-019. 10.15580/GJETS.2014.1.012914084.

McGhee, D. E., Lowell, N. \&Lemire, S. (2007). The Classroom Learning Environment (CLE) Questionnaire: Preliminary Development. OEA Report 06-07. Retrieved from $<$ https://www.washington.edu/assessment/>.

Mishra, L. (2011, September). Pre-Service Teacher Training for Peace Education. International Journal of Peace and Development Studies, vol.2:7, pp.203-210.

National Education Policy (2017). Ministry of Federal Education and Professional Training Government of Pakistan. 
Obidike, N.D., Bosah, I. \& Olibie, E. (2015). Teaching Peace Concept to Children. International Journal of Multidisciplinary Research and Development, vol.2:6, pp.24-26.

Omirin, D. \& Funke, F. (2015). Perception of Teachers on the Influence of Peace Education in the South-West Nigerian Secondary Schools. Global Journal of Human-Social Science, vol.15:7, pp.31-38.

Roof, D.J. (2015). Problems of Common Interest: The Shaping of Education in Pakistan, 1970-2014. Pakistan Journal of Commerce and Social Sciences, vol.9:1, pp.35-51.

S.H. Khan, M. Saeed . (2010). Evaluating the quality of Bed. program: Students' views of their college experiences.Teaching and Teacher Education an international journal of research and studies.26:760-766.

Salomon \& Cairns. (2011). Handbook on Peace Education, Google Books Result, https://books.google.com.pk/books?isbn=1136874526

Shumaila Bhutto, S. N. (2014). Peace Themes in School Studies in Pakistan- An Exploratory View. International Journal of Multidisciplinary and Current Research, vol.2, pp.2321-3

Sakade, N. (2009). Peace Education in Ppractice?A Case Study of Peace Education in England. Birmingham, England.

Sri-Amnuay, Aree. (2011). Developing a Model of Peace Education in the Undergraduate Teacher Training Process for Early Childhood Education at Rajabhat Universities. Thailand : Northumbia Universitiy.

UNESCO. (2005). Peace Education; Framework for Teacher Education. New Dehli, India.

Dr. Aziz-Un-Nisa is an Assistant Professor in the Department of Education, University of Karachi.

Ms. Sajida Parveen is Ph.D Scholar in the Department of Teacher Education, University of Karachi. 